HR Human Rights Education Review

\title{
EDITORIAL
}

\section{Human Rights Education: A Project for Our Common Future}

\author{
Audrey Osler \\ Editor-in-chief \\ University of South-Eastern Norway, Norway \\ University of Leeds, UK.
}




\title{
EDITORIAL
}

\author{
Human Rights Education: A Project for Our Common Future \\ DOI: http://doi.org/10.7577/hrer.2805 \\ ISSN 2535-5406 \\ Audrey Osler \\ Editor-in-chief \\ University of South-Eastern Norway, Norway \\ University of Leeds, UK. \\ A.H.Osler@leeds.ac.uk
}

It is with great pleasure, and a considerable sense of anticipation, that the University of South-Eastern Norway is launching Human Rights Education Review. The University is building a body of expertise both in the fields of human rights and human rights education within and beyond the Faculty of Humanities, Sports and Educational Science. It therefore seems particularly appropriate that human rights education should be the focus of the USN's first open access scholarly journal.

Increasingly, scholars across the globe are seeking ways of sharing their research without the restrictive access generally imposed by the paywalls of scholarly journals. Open access journals give us this freedom. Paywalls not only work against the advancement of knowledge but may also serve to act against key human rights principles. We are therefore proud to host Human Rights Education Review as an open-access forum for debate and scholarship that is both critical and engaged.

In 2010, I joined the team at the University of South-Eastern Norway to develop our international MSc programme in Human Rights and Multiculturalism. To date, we have seen around 100 students from all parts of the globe pass through our programme, which remains unique within Europe in combining human rights teaching and learning, and multicultural perspectives within an interdisciplinary framework. A number of doctoral candidates are also working on human rightsbased research themes at USN and so it is perhaps only natural that our Faculty should elect to support HRER as the University's first open access, peer-reviewed scholarly journal. We hope that HRER will become a first port-of-call for scholars, students, and all those engaged in human rights education research and human rights-based teaching and learning.

Human Rights Education Review aims to provide a forum for research and critical scholarship on human rights and diversity in education. The journal is dedicated to a critical examination of human rights education theory, philosophy, policy and praxis. HRER provides opportunities for scholars to contribute to debates and critical thinking in the expanding field of human rights education and addresses these fields as they relate to citizenship, identity and belonging.

Human Rights Education Review seeks to fill a gap by providing a forum for scholarship that enables a critical analysis of human rights education. Societal diversity generally enhances democratic practices (Banks et al., 2005; Parker, 2003) and, I contend, strengthens understandings of human rights. By promoting research that addresses both human rights and diversity in education, the aim is to shed new light on core political, economic and societal challenges facing teachers and learners. As the impact of globalization is felt at local, national, and international levels, so various actors, including those engaged in education policy and praxis, need to 
respond to challenges posed by conflicts, economic disparities, migration and global inequalities. The increase in violence, racism, extremism, discrimination and intolerance demands an educational response.

The roots of human rights education can be traced back over many centuries through efforts to promote human dignity, justice and freedom, and it is noteworthy that the modern human rights project envisioned education at its core. Those who drafted the 1948 Universal Declaration of Human Rights (UDHR) (UN, 1948) recognised education as central to the realisation of justice and peace, and this vision has been encapsulated in subsequent human rights instruments. While the right to education articulated in Article 26 of the UDHR is broadly recognised, the right to human rights education which is also encapsulated in this Article remains less familiar, even among education scholars.

Over the years, efforts to promote key human rights principles through education and awareness-raising projects have continued across the globe at grassroots level, as well as in schools and universities, often in response to authoritarian regimes. The field of work has expanded greatly from when I was first introduced to the concept of human rights education at a Council of Europe teachers' seminar in Denmark in 1986. The need for human rights education in the early decades of the twenty-first century is more widely recognised than in the more optimistic decades at the end of the twentieth century (Ó Cuanacháin, 2010).

Yet schooling has also frequently been used to undermine human solidarity and foster conflict and violence (Harber, 2004). In the second decade of the twentyfirst century, parallels are being drawn between the current global political climate and that of the period preceding World War Two, when authoritarian states sought to promote ethno-nationalism, conflict and hatred through education.

Struggles for justice remain diverse in their approaches, styles and orientation. Likewise, education for human rights, justice and peace takes many forms. Human Rights Education Review welcomes contributions from a variety of disciplinary perspectives. The composition of our international editorial board, with scholars from Africa, Australasia, North America, Latin America, and Europe, reflects our aspiration to build theory and praxis from a global knowledge base.

\section{Our inaugural issue}

This first issue of HRER brings together four invited peer-reviewed articles, together with a review article and two further book reviews. In calling for these four contributions, we were conscious of the need to strengthen and extend the field of human rights education, by mixing established scholars with new voices and provoking friendly challenges to human rights educators from those working in related fields. In the first paper in Volume 1(1), Walter C. Parker offers one such challenge. Focusing on the United States, he claims that human rights education curricula are 'at best opaque and at worst under-developed'. He argues for a greater emphasis on powerful, disciplinary knowledge in schools that will extend students' experiences and enable HRE to realise its social justice mission and emancipatory promise.

Marta Bivand Erdal and Mette Strømsø report on research that sets out to explore students' understandings of national belonging. Their respondents are upper secondary school students in Oslo, Norway, where 33 per cent of the population are either immigrants or the children of immigrants. Their paper seeks to explore the relationship between young people's right to participate and the possibilities and 
limitations of schools that are engaged in a project of nation-building. They consider the implicit and explicit ways in which students and teachers engage in the production and reproduction of the nation. They identify concrete ways in which children's human rights might be extended through the co-construction of national belonging in classrooms characterised by diversity, through processes that might eventually contribute to a more inclusive society and more inclusive conception of citizenship.

In our third article in this edition of HRER, Alicia Muñoz Ramírez reports on a very recent struggle between advocates for the development of democratic citizenship education and human rights education in twenty-first century Spain and their opponents, led by neoconservative actors within the hierarchy of the Spanish Catholic church and society. The latter group eventually succeeded in removing Education for Citizenship and Human Rights from the Spanish school curriculum. The relevance of this article extends way beyond Spain, reflecting similar tensions and struggles in contemporary European societies and in nations much further afield. Indeed, the Spanish case also highlights elements of a much longer struggle, since 1789 , between the power of institutional religion and secular rationality.

In the final peer-reviewed article in this edition, Sonja Grover makes the case for a stronger focus on law within human rights education in schools. Acknowledging current attempts to further child participation, she argues that education for civic engagement is insufficient. She proposes the study of child-led public litigation cases within the school curriculum, arguing that such study might more effectively support children in advancing their rights through the courts. She takes one such child-led case, addressing environmental protection, to illustrate her argument.

Human rights education is now recognised as a legitimate field of research. The four papers presented here illustrate diverse approaches to HRE scholarship and research. They offer a critique of current practices and suggest alternative ways forward. The editors of HRER trust they may offer readers starting points for dialogue on education for justice in troubled times. Together they highlight ways forward in reimagining our common future.

\section{Acknowledgements}

The establishment of a new journal requires a great deal of dedication, hard work and support. The editors, Ingrid Reite Christensen, Audrey Osler and Ådne ValenSendstad, would like to thank the University of South-Eastern Norway's (USN) Library Service and particularly Frode Bakken for support and guidance as we set out together on this learning journey at USN. We also acknowledge the valuable advice and technical support of Trude Eikebrokk and her team at Oslo Metropolitan University. We are grateful for the support and long-term commitment to this project shown by Arild Hovland, Dean of the Faculty of Humanities, Sports and Educational Science and Tone Strøm, Head of the Department of Culture, Religion and Social Studies at USN. Importantly, we continue to draw on the advice, encouragement, and practical support of members of our wonderful International Advisory Board. David Glass has provided us with invaluable behind-the-scenes professional support, as have a large number of anonymous reviewers. Most importantly, our colleague and Associate Editor, Gabriela Mezzanotti, has been a hard-working anchor in this project, linking editors, copy editor, international board members, and many other colleagues to provide us with the most efficient, professional, courteous, and always- 
smiling service. We look forward to the next stage of the journey and to marking the formal launch seminar of the journal on 26 September 2018 in Drammen.

\section{References}

Banks, J. A., McGee Banks, C. A., Cortes, C. E., Hahn, C. L., Merryfield, M. M., Moodley, K. A. ...Parker, W. C. (2005). Democracy and diversity: Principles and concepts for educating citizens in a global age. Seattle, WA: University of Washington, Center for Multicultural Education.

Harber, C. (2004). Schooling as violence: How schools harm pupils and societies. New York, NY: RoutledgeFalmer.

Ó Cuanacháin, C. (2010). Preface, In Osler, A. \& Starkey, H. Teachers and human rights education. Stoke-on-Trent, UK: Trentham, pp. xi - xiii.

Parker, W.C. (2003). Teaching democracy: Unity and diversity in public life. New York, NY: Teachers College Press.

United Nations (1948). Universal Declaration of Human Rights. Retrieved 21.06.2018 from http://www.un.org/en/universal-declaration-human-rights/ 